\title{
Yield and Quality of Mung Bean (Vigna radiata (1.) R. Wilczek) Seeds Produced in Poland
}

\author{
Kamil MISIAK ${ }^{1 *}$, Barbara GÓRNA², Ewelina KRÓL ${ }^{3}$, Roman HOŁUBOWICZ ${ }^{1}$ \\ ${ }^{1}$ Department of Plant Pathology, Seed Science and Technology, University of Life Sciences, \\ Dojazd 11, 60-637 Poznań Poland \\ ${ }^{2}$ Department of Fermentation and Biosynthesis, Poznań University of Life Sciences, Poland \\ ${ }^{3}$ Department of Human Nutrition and Hygiene, Poznań University of Life Sciences, Poland \\ ${ }^{*}$ Corresponding author, e-mail: kamil20km@gmail.com
}

Bulletin UASVM Horticulture 74(2)/ 2017

Print ISSN 1843-5254, Electronic ISSN 1843-5394

DOI:10.15835/buasvmcn-hort: 0035

\begin{abstract}
The aim of the experiment was to do field and laboratory assessments of yield and quality of mung bean (Vigna radiata (L.) R. Wilczek) seeds cultivated in Western Poland. Mean yield of seeds per plant was higher for common bean (Phaseolus vulgaris L.) than for mung one: $13.1 \mathrm{~g}$ and $2.58 \mathrm{~g}$, respectively. The mean 1000 mung seeds weight was $50.9 \mathrm{~g}$ and their germination $-78 \%$. Germination capacities of seeds of both beans in the field were similar. Mung beans, compared to common bean, had much smaller seeds, started to bloom later and produced mature seeds later than the latter. Mung bean seeds had more total proteins and Magnesium and Copper than common bean seeds. In Western Poland, production of high quality mung bean seeds was possible.
\end{abstract}

Keywords: bean seed yield, bean seed quality, mung bean

\section{INTRODUCTION}

Mung bean (Vigna radiata (L.) R. Wilczek) belongs to the Fabaceae botanical family and to the genus Vigna. The species comes from India, where it was domesticated about 4,500 years ago (Fuller, 2007). It is currently cultivated mainly in South and Southeast Asia, especially in India, China (Zhang et al., 2003) and Pakistan, and to a smaller extent also in some parts of Africa, the U.S. (especially in Oklahoma) and Australia (Smýkal et al., 2015). Ninety per cent of the world's mung bean production is in Asia, including India, where around $50 \%$ of the species world's production is located (Pandiyan et al., 2011).The biggest exporter of mung bean seeds has been China (Cheng and Tian, 2011). So far, the crop has never been produced in Poland, although, last few years, its seeds were imported and used for sprout production (Anonymous, 2016).

Mung bean is a valuable food for humans and animals. It is consumed as green pods and seeds, dry seeds as well as young shoots (Kahraman et al., 2014). This plant has been a very good source of proteins, carbohydrates and mineral salts. One of the most important uses of mung beans are sprouts (Zhang et al., 2003; Lim 2012; Thippeswamy et al., 2015). The seeds are also used in pharmaceutical and cosmetic industries (Shaheen et al., 2012).

The main purpose of this research was to find out, if mung bean can be produced in Poland and evaluate its seeds yield and quality. The check seeds were common bean seeds, because in the climatic conditions of Poland, the most popular beans are common (Phaseolus vulgaris L.) and runner beans (Phaseolus coccineus L.)(COBORU, 2017).

\section{MATERIALS AND METHODS}

Mung (cv. unknown, produced for dry seeds) and common beans (Phaseolus vulgaris L.) cv. Igołomska (produced for dry seeds) seeds from the seed company W. Legutko were used for the 
experiment. Field experience was conducted in 2016 at the Experiment Station of the Faculty of Horticulture and Landscape Architecture Marcelin of Poznań University of Life Sciences (PULS) in Western Poland.

Seeds were sown on June $4^{\text {th }}, 2016$, on the podsol formed on the clay soil field plot of the size $10.5 \mathrm{~m} \times 4.4 \mathrm{~m}$. Then, it was divided into 8 smaller plots: each of them had 5 rows spaced apart $30 \mathrm{~cm}$ and $2 \mathrm{~m}$ long. Each small plot was treated as one replication. The experiment was a randomized block layout. In each replication (small plot), 280 mung bean and 200 common bean seeds were sown. Before sowing them, they were treated with a chemical against bean seed maggot (Hylemyia florilega Zett.).

The weeding, irrigation and fertilization were done routinely as in other bean crop.

During the growth of the plants, some plants' characters were recorded. They included seeds germination rates and plant emergence in the field, carried out 7 and 14 days after sowing the seeds and then flowering of plants. In the last one, 10 plants from each plot were randomized for the study. Altogether, it gave 4 replications of 10 plants each for flowering evaluation, then compared for 4 following decades. The date of blossoming of the first flower, blooming period, and the distribution of flowering in time (flowering peak) were also determined. The other observations included measuring the plant's total height, number of pods per plant, number of seeds in pod and seed yield per 1 plant. Plants throughout the growth period were also evaluated for diseases and pests susceptibility.

Before sowing and after harvesting the seeds, the other plants' characters were measured. They included: length, width and thickness of seeds. They were done with a slider to the nearest 0.01 $\mathrm{mm}$ to observe changes in selected geometric features and weighed to $0.0001 \mathrm{~g}$ to determine seed weight variability. All measurements were done in 3 replications of 100 individual seeds. The other evaluated parameters included seed germination and 1000 seed weight following the rules of the International Seed Testing Association (ISTA) (Anonymous, 2012). For the seed germination test, plastic containers $(21.5 \mathrm{~cm} \times 16.5 \mathrm{~cm} \times 6.5 \mathrm{~cm})$ filled with sterilized river sand of the granularity of 0.05 to $0.08 \mathrm{~mm}$ were used. One hundred mung bean seeds and 50 bean seeds in 4 replications were tested at $25^{\circ} \mathrm{C}$. The germination energy evaluation (first seeds counting) for mung and common beans was done at the same time, i.e. after 5 days, and germination capacity evaluation (final seeds counting) were done 2 and 4 days later, respectively. In the latter, normal and abnormal seedlings as well as fresh and dead seeds were also counted (Anonymous, 2012).

The harvested mung bean seeds, after their drying at room temperature, to the water content of $8.93 \%$, were analyzed for their dry matter, ash, carbohydrates, total proteins, fats and chemical elements such as: Calcium (Ca), Magnesium (Mg), Iron (Fe), Zinc ( $\mathrm{Zn}$ ) and Copper (Cu). It was carried out at the Division of Food Hygiene and Toxicology at the Faculty of Food Science and Nutrition, Poznań University of Life Sciences. The dry matter was determined by the commonly used the drier's method (Drzazga, 1999), ash by muffle furnace combustion (Iwańska et al., 1964), total proteins by the Kjeldahl's method (Bobrzański, 1956), fats by the Soxhlet's method (Stepnowski et al., 2010), and carbohydrates were calculated from 100\% difference (protein content + fat content + ash content + water content). Mineral components: $\mathrm{Ca}, \mathrm{Mg}, \mathrm{Fe}, \mathrm{Zn}$ and $\mathrm{Cu}$ were determined by using atomic absorption spectrometry (AAS) - AAS-3 (Ditrich, 1988; Borkowska-Burnecka, 2012).

The weather conditions for growing beans that year in Poland can be described as medium good. It was a little cooler than normally in July and August, but warmer in June and September (Tab. 1). In July, it was much more rains than normally, but then, in August and September, it was dry on the field (Tab. 1). Both vegetation period and mean air day temperatures are different for Eastern and Western Poland. In the latter, the vegetation period is 20 days longer and the air temperature is $0.5-1^{\circ} \mathrm{C}$ higher than in the first one (Molga, 1983).

All the results from received in the studies were statistically analyzed using the STAT programme. Analysis of variance was carried out and the Duncan's test at $\alpha=0.05$ was used to mark significant differences. Mean values for a given character, which differed significantly from one another, were marked with different letters.

\section{RESULTS AND DISCUSSION}

Common bean seeds, when measured 7 days after sowing them in the field, emerged much better than the mung beans ones (Tab. 2). However, one week later that difference disappeared. Common 
Tab. 1. Average daily air temperature $\left[{ }^{\circ} \mathrm{C}\right]$ and sums of monthly rainfalls $[\mathrm{mm}]$ for Poznań 2016 and the average values of these parameters for the years 2006-2015 during the period of the field experiment with the mung and common beans

\begin{tabular}{lcccc}
\hline \multirow{2}{*}{ Month } & \multicolumn{2}{c}{ Average daily air temperature $\left[{ }^{\circ} \mathbf{C}\right]$} & \multicolumn{2}{c}{ Sum of rainfalls $[\mathbf{m m}]$} \\
\cline { 2 - 5 } & $\mathbf{2 0 1 6}$ & $\mathbf{2 0 0 6 - 2 0 1 5}$ & $\mathbf{2 0 1 6}$ & $\mathbf{2 0 0 6 - 2 0 1 5}$ \\
\hline June & 18.88 & 17.59 & 74.3 & 65.1 \\
\hline July & 19.47 & 20.44 & 128.3 & 86.48 \\
\hline August & 18.15 & 19.19 & 36.3 & 64.34 \\
\hline September & 17.06 & 14.58 & 3.4 & 35.55 \\
\hline October & 8.26 & 9.09 & 75.0 & 27.59 \\
\hline
\end{tabular}

Note: data from the Institute of Meteorology and Water Management for Poznań

Tab. 2. Field emergences (\%) of mung and common beans in the field 7 and 14 days after sowing their seeds

\begin{tabular}{ccc}
\hline Bean & after 7 days & after 14 days \\
\hline Mung & $57.9 \mathrm{~b}^{*}$ & $66.2 \mathrm{a}$ \\
\hline Common & $28.1 \mathrm{a}$ & $66.1 \mathrm{a}$ \\
\hline
\end{tabular}

*Means followed by the same letter are not significantly different according to the Duncan's test for $\alpha=0.05$

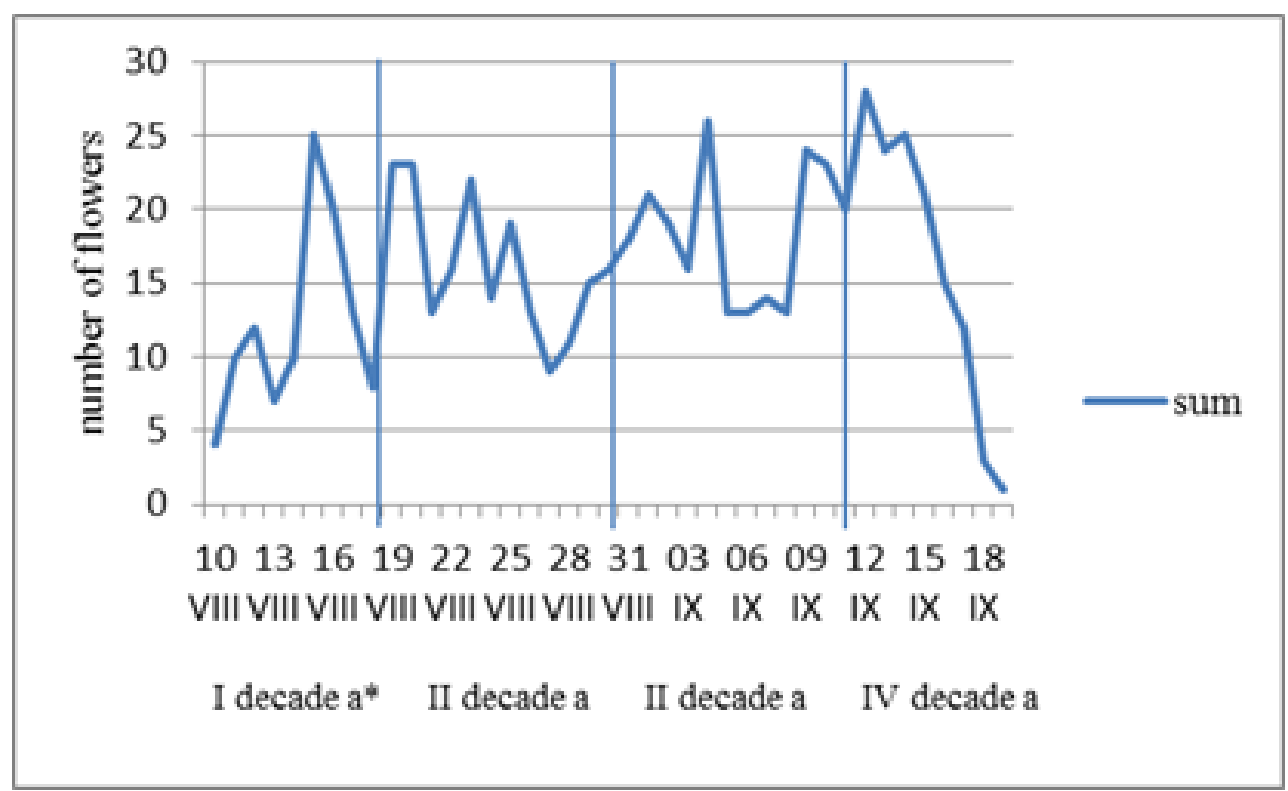

Fig. 1. Daily sums of blooming mung bean flowers in 10 randomized plants in the field for the following 40 days starting on August $10^{\text {th }}, 2016$. Vertical: number of blooming flowers, horizontal: dates in 4 decades: from Aug. $10^{\text {th }}$, till Sept. $19^{\text {th }}$.

*Means followed by the same letter are not significantly different according to the Duncan's test for $\alpha=0.05$ 
bean plants started flowering on July $16^{\text {th }}$ and ended on July $29^{\text {th }}$, whereas the latter - on August $10^{\text {th }}$ and September $19^{\text {th }}$, respectively. For mung bean, there was neither clear differences nor one flowering peak in terms of the recorded number of blooming flowers throughout the whole flowering period lasting 40 days (Fig. 1). According to the results received by Canci and Toker (2014), the average number of days to blossom, depended on the cultivar and ranged from 20 to 76 days, and the recorded mean value was 58 days.

Table 3 shows selected morphological characteristics of the mung and common beans. The total heights of the plants of both beans plants were about $40 \mathrm{~cm}$ and were not different. Both species had also similar number of pods per plant - about 9. On average, mung bean had 6.3 seeds per pod, whereas common one - about 4 seeds. Mean yield of seeds per plant was higher for common bean than for mung one: $13.1 \mathrm{~g}$ and 2.58 g, respectively (Tab. 3). According to Canci and Toker (2014), the average height of the mung bean plant varies from 19.5 to $91 \mathrm{~cm}$, whereas the average number of pods - from 8 to 62 with 5 to 13 seeds per one pod. With an average density of 46 mung bean plants per $1 \mathrm{~m}^{2}$ (plant spacing $7 \mathrm{~cm}$ x $30 \mathrm{~cm}$ ), the average recalculated seed yield in this experiment was $29.08 \mathrm{~g} / \mathrm{m}^{2}$. For the common bean seeds, with the density ratio of 42 plants per
$1 \mathrm{~m}^{2}$ (plant spacing $8 \mathrm{~cm} \times 30 \mathrm{~cm}$ ), recalculated seed yield in this experiment was $384 \mathrm{~g} / \mathrm{m}^{2}$.

Although, the length, thickness and weight of the mung beans seeds before sowing and after harvest were not different (Table 4), still Chinese seeds were wider than the ones harvested in Poland. Despite this recorded difference, the received by us seed size parameters were in the range of values given in other papers by Nimkar and Chattopadhyay (2001), Mangaraj et al. (2005), Yildiz (2005) and Unal et al. (2008).

Although, the germination energy (Fig. 2) of the mung bean in the laboratory was better than the one counted for common bean seeds by as much as $36.5 \%$, still eventually the recorded seed germination capacities for both species were the same. That included also the number of abnormal seedlings and fresh seeds, while the number of dead seeds was higher for mung bean than for the common one. The recorded in our experiment seed germination ability for mung bean was 78.25. It was in the range of values from $67.3 \%$ to $97.5 \%$ given by Chiangmai et al. (2006). The recorded in our experiments 1000 seed weight for mung bean was 50.85 , i.e. it was almost 6 times lower than for the common one (Tab. 5). It was in the range of values from 33.4 to 55.8 g given by Khattak et al. (2003).

Although, the contents of dry matter and ash in mung and common beans seeds were the

Tab. 3. Selected plant characters of mung and common bean plants evaluated in the field

\begin{tabular}{ccccc}
\hline Bean & $\begin{array}{c}\text { Total plant's height } \\
{[\mathbf{c m}]}\end{array}$ & $\begin{array}{c}\text { Number of pods per } \\
\text { plant }\end{array}$ & $\begin{array}{c}\text { Number of seeds } \\
\text { per pod }\end{array}$ & $\begin{array}{c}\text { Seed yield per plant } \\
{[\mathrm{g}]}\end{array}$ \\
\hline Mung & $40.45 \mathrm{a}^{*}$ & $9.3 \mathrm{a}$ & $6.3 \mathrm{~b}$ & $2.58 \mathrm{a}$ \\
\hline Common & $40.20 \mathrm{a}$ & $9.9 \mathrm{a}$ & $4 \mathrm{a}$ & $13.1 \mathrm{~b}$ \\
\hline
\end{tabular}

*Means followed by the same letter for a given character are not significantly different according to the Duncan's test for $\alpha=0.05$

Tab. 4. Comparison of selected morphological seeds characters, i.e. length, width and thickness and a single seed weight, of the mung beans seeds from China used for sowing in the experiment and the seeds harvested in it in Poland

\begin{tabular}{cccccc}
\hline Bean & Evaluation date & length $[\mathbf{m m}]$ & width [mm] & thickness [mm] & weight of $\mathbf{1}$ seed [g] \\
\hline \multirow{2}{*}{ Mung } & before sowing & $4.7 \mathrm{a}^{*}$ & $3.9 \mathrm{~b}$ & $3.9 \mathrm{a}$ & $0.0543 \mathrm{a}$ \\
\cline { 2 - 6 } & after harvest & $4.7 \mathrm{a}$ & $3.7 \mathrm{a}$ & $3.8 \mathrm{a}$ & $0.0505 \mathrm{a}$ \\
\hline
\end{tabular}

*Means followed by the same letter for a given character are not significantly different according to the Duncan's test for $\alpha=0.05$ 


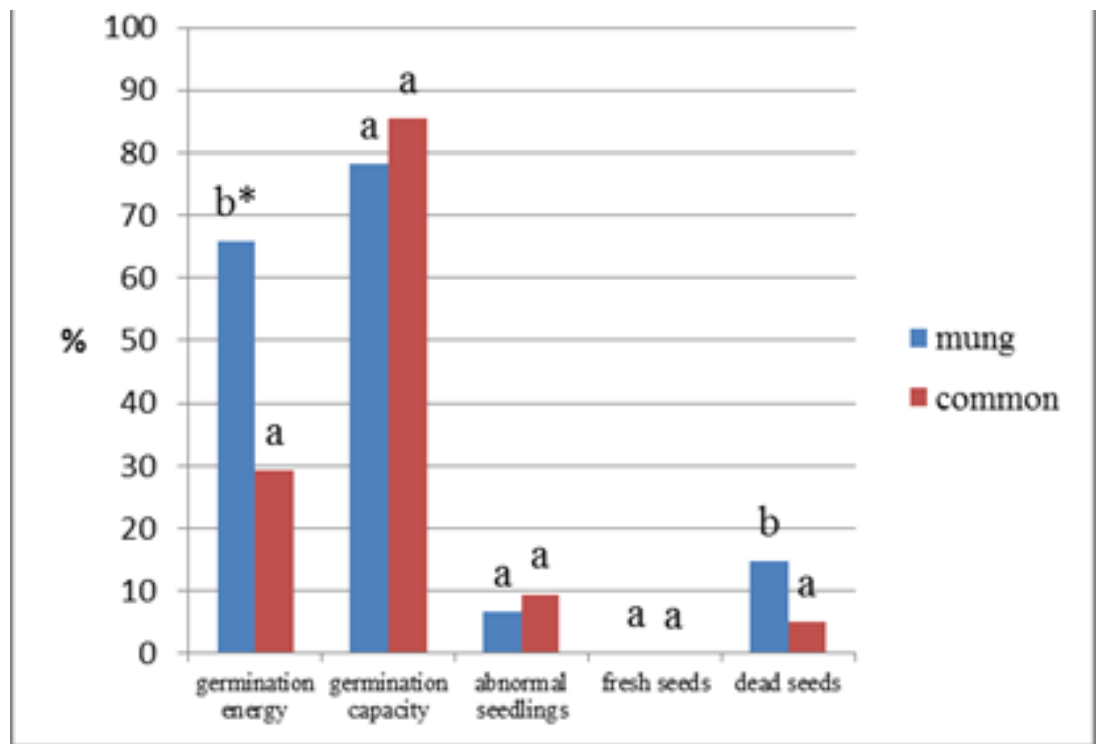

Fig. 2. Seed germination energy and capacity of mung (blue) and common (red) beans.

Vertical: germination (\%), horizontal from the left: germination energy, germination capacity, abnormal seedlings, fresh seeds, dead seeds.

*Means followed by the same letter for a given character are not significantly different according to the Duncan's test for $\alpha=0.05$

Tab. 5. Thousand seeds weight of mung and common beans

\begin{tabular}{|c|c|}
\hline Bean & $\mathbf{1 0 0 0}$ seed weight [g] \\
\hline Mung & $50.85 \mathrm{a}^{*}$ \\
\hline Common & $326.55 \mathrm{~b}$ \\
\hline
\end{tabular}

*Means followed by the same letter are not significantly different according to the Duncan's test for $\alpha=0.05$

Tab. 6. Comparison of selected nutrients content in mung and common beans

\begin{tabular}{cccccc}
\hline \multirow{2}{*}{ Bean } & \multicolumn{5}{c}{ Nutrients [\%] } \\
\cline { 2 - 6 } & Dry weight & Ash & Carbohydrates & Proteins & Fats \\
\hline Mung & $91.07 \mathrm{a}^{*}$ & $4.11 \mathrm{a}$ & $63.60 \mathrm{a}$ & $22.58 \mathrm{~b}$ & $0.79 \mathrm{a}$ \\
\hline Common & $91.12 \mathrm{a}$ & $3.88 \mathrm{a}$ & $66.01 \mathrm{~b}$ & $20.19 \mathrm{a}$ & $1.04 \mathrm{~b}$ \\
\hline
\end{tabular}

*Means followed by the same letter for a given character are not significantly different according to the Duncan's test for $\alpha=0.05$

Tab. 7. Comparison of selected macro- and microelements in seeds of mung and common beans

\begin{tabular}{cccccc}
\hline \multirow{2}{*}{ Bean } & \multicolumn{5}{c}{ Chemical elements [ $\boldsymbol{\mu g} / \mathbf{g}$ d. m.] } \\
\cline { 2 - 6 } & Ca & Mg & Fe & Zn & Cu \\
\hline Mung & $1269.03 \mathrm{a}^{*}$ & $2099.93 \mathrm{~b}$ & $56.02 \mathrm{a}$ & $40.57 \mathrm{a}$ & $7.17 \mathrm{~b}$ \\
\hline Common & $1607.41 \mathrm{~b}$ & $1398.82 \mathrm{a}$ & $71.75 \mathrm{~b}$ & $42.90 \mathrm{a}$ & $4.55 \mathrm{a}$ \\
\hline
\end{tabular}

*Means followed by the same letter for a given character are not significantly different according to the Duncan's test for $\alpha=0.05$ 
same (Tab. 6), still the seeds of first one had less carbohydrates and fats and more total proteins than the latter one. These results are in agreement with the data received by Khattak et al. (2003), Mubarak (2005) and Dahiya et al. (2015). The mung bean seeds had more $\mathrm{Mg}$ and $\mathrm{Cu}$ and less $\mathrm{Ca}$, $\mathrm{Fe}$ and $\mathrm{Zn}$ than the common bean seeds (Tab. 7). Our values of Fe and $\mathrm{Zn}$ were the same and $\mathrm{Mg}$ and $\mathrm{Ca}$ - higher and $\mathrm{Cu}$ - lower than the results received by Dahiya et al. (2015).

\section{CONCLUSIONS}

In Western Poland, production of high quality mung bean seeds was possible. This bean, compared to common bean, had smaller seeds and later than the latter reached blooming and maturity of the seeds. Mean yield of seeds per plant was higher for common bean than for mung one: $13.1 \mathrm{~g}$ and $2.58 \mathrm{~g}$, respectively. They had 1000 seeds weight of $50.85 \mathrm{~g}$ and germinated in $78 \%$. The most stable characters of mung bean seeds in this experiment, were their length and thickness and seed weight, whereas the least stable - their width. The mung bean seeds had $22.58 \%$ proteins compared to $20.19 \%$ in common beans and more $\mathrm{Mg}$ and $\mathrm{Cu}$ than common bean seeds.

Acknowledgements. This research did not receive any specific grant from funding agencies in the public, commercial, or non-profit sector.

\section{REFERENCES}

1. Anonymous (2012). International Rules For Seed Testing Edition 2012. The International Seed Testing Association (ISTA), Bassersdorf, ISBN 13 978-3-906549-68-2.

2. Anonymous (2016). W. Legutko seed company catalogue (in Polish).

3. Bobrzański B (1956). Quantitative analysis of organic compounds. PWN, Warsaw (in Polish).

4. Borkowska-Burnecka J (2012). Spectro-chemical analysis. PWN, Warsaw (in Polish).

5. Canci H, Toker C (2014). Yield components in mung bean [Vigna radiata (L.) Wilczek]. Turk. J. Field Crops 19(2): 258-261.

6. Cheng X, Tian J (2011). Status and Future Perspectives of Vigna (Mungbean and Azuki bean) Production and Research in China. In: N Tomooka, DA Vaughan (eds.). 14th NIAS int. workshop on genetic resources - Genetic resources and comparative genomics of legumes (Glycine and Vigna). Natl. Inst. Agrobiol. Sci, Tsukuba (pp: 83-86).

7. Chiangmai PN, Laosuwan P, Waranyuwat A (2006). The effect of mung bean seed size on germination ability, bean sprout production and agronomic characters. Silpakorn Univer. Int. J. 6 (1-2): 170-190.

8. COBORU - Lista odmian roślin warzywnych wpisanych do krajowego rejestru w Polsce. W: Centralnego Ośrodka Badania Odmian Roślin Uprawnych w Słupi Wielkiej. (2017). http://www.coboru.pl/Publikacje_COBORU/ Listy_odmian/lo_warzywne_2 017 .pdf.Accessed 2017.06.21.

9. Dahiya PK, Linnemann AR, Van Boekel MA, Khetarpaul N, Grewal RB, Nout MJ (2015). Mung Bean: Technological and Nutritional Potential. Crit. Rev. Food Sci. Nutr. 55(5): 670-688.

10. Ditrich K (1988). Absorbic atomic spectro-photometry. PWN, Warsaw (in Polish).

11. Drzazga B (1999). Analiza techniczna w przemyśle spożywczym. WSiP Warszawa.

12. Fuller DQ (2007). Contrasting patterns in crop domestication and domestication rates: recent archaeobotanical insights from the Old World. Ann. Bot. 100(5): 903-924.

13. Iwańska I, Litewka L, Pietrzyk C (1964). Methods of investigation of food products. PWN, Warsaw, 83-86 (in Polish).

14. Kahraman A, Adali M, Onder M, Koc N (2014). Mung Bean [Vigna radiata (L.) Wilczek] as Human Food. Int. J. Agric. Econ. Dev. 2(2): 9-17.

15. Khattak GSS, Zamir R, Muhammad T, Shah SA (2003). Breeding mungbean (Vigna radiata (L.) Wilczek) genotypes for the agro-climatic conditions of NWFP. Pak. J. Bot. 35(5): 763-770.

16. Lim TK (2012). Vigna radiata. In: TK Lim, Edible Medicinal And Non-Medicinal Plants: Volume 2, Fruits. Springer Science+Business Media B.V., New Delhi, 951-959.

17. Mangaraj S, Agrawal S, Kulkarni SD, Kapur T (2005). Studies on physical properties and effect of pre-milling treatments on cooking quality of pulses. J. Food Sci. Technol. 42: 258-262.

18. Molga M (1983). Agricultural Meteorology. Państwowe Wydawnictwo Rolnicze i Leśne, Warsaw, 172 (in Polish).

19. Mubarak AE (2005). Nutritional composition and antinutritional factors of mung bean seeds (Phaseolus aureus) as affected by some home traditional processes. Food Chem. 89(4): 489-495.

20. Nimkar PM, Chattopadhyay PK (2001). Some physical properties of green gram. J. Agric. Eng. Res. 80: 183-189.

21. Pandiyan M, Senthil N, Ramamoorthi N, Ganesh SK (2011). Present status and future perspectives of Glycine and Vigna in India. In: N Tomooka, DA Vaughan (eds.). The 14th NIAS international workshop on genetic resources Genetic resources and comparative genomics of legumes (Glycine and Vigna). Natl. Inst. Agrobiol. Sci. Tsukuba (pp.: 53-60).

22. Shaheen S, Harun N, Khan F, Hussain RA, Ramzan S, Rani S, Khalid Z, Ahmad M, Zafar M (2012). Comparative nutritional analysis between Vigna radiata and Vigna mungo of Pakistan. Afr. J. Biotech. 25(11): 6694-6702.

23. Smýkal P, Coyne CJ, Ambrose MJ, Maxted N, Schaefer H, Blair MW, Berger J, Greene SL, Nelson M, Besharat N, 